\title{
An investigation of physical activity promotion plans for female students: Action research on SPARK program based soccer class
}

\author{
Tae yang Yang ${ }^{1} \&$ Gyu il Lee $^{2 *}$ \\ ${ }^{1}$ Yangduk Middle School \& ${ }^{2}$ Kyungpook National University
}

\begin{abstract}
[Purpose] The purpose of this study is to explore the physical activity promotion plans for female student by revising and supplementing the SPARK program which is actively applied as a P.E physical activity improvement program recently. [Methods] To achieve this, this study followed the custom of action research and apprehended problem in female students' physical activity in SPARK soccer program(first action and examination), problem solving plan(replanning), execution and evaluation of replanned SPARK soccer program (second action and evaluation). The collection and analysis of data was conducted by sequential explanation strategy. Specifically, the study utilized 3 dimensional accelerometer to measure the physical activity in P.E class, and collected data which could apprehend the experience of students by utilizing qualitative study tools(observation, class note, interview). To analyze the collected data, the study utilized mixed-methods study analysis method developed by Greene(2007). [Results] The study results are as follows. As for the result of first action(October November 2014), SPARK program increases the entire physical activity in P.E class, but the female students' activity was relatively lower than male students'. The reasons for lower physical activity of female students' were unmotivated class, burdensome class, alienated class. These were specified into teaching strategy to replan and execute the second action (May June 2015). Compared to first action, the second action showed positive physical activity, and the MVPA of female students' showed statistical difference $(<.01)$. As for the result of qualitative analysis, the positive grounds of second action are 1) motivative resource like "necessity", 2)hard but meaningful learning activity, and 3)kind P.E teacher. [Conclusions] In conclusion, the implementation of a soccer class with a modified supplement to the SPARK program can enhance physical activity of female middle school students.
\end{abstract}

Key words: Physical activity, SPARK program, Moderate to vigorous physical activity(MVPA), Female students, Action research, Sequential explanation strategy

논문 투고일 : 2020. 01. 29.

논문 수정일 : 2020. 03. 23.

게재 확정일 : 2020. 04. 06.

* 교신저자 : 이규일 (mauri94@knu.ac.kr).

* 본 연구는 2017년 양태양의 석사학위 논문(SPARK 프로그램 활용 중학교 1 학년 축구수업 실행연구)에 사용된 자료를 토대로 새롭게 구성한 논문이다.

\section{서 론}

청소년기 건강의 목적은 발달(development)에 있다. 건강발달은 에너지소비량 기준 $3 \mathrm{METS}$ 이상의 활동을 의 미하는 중-고강도 신체활동(Moderate to Vigorous Physical Activity, 이하 MVPA)을 필요로 한다. 청소년 기 MVPA는 비만 예방 및 심혈관 건강, 근골격계 건강을
\end{abstract}


포함한 신체적 발달(Strong et al, 2005), 우울증의 감소 및 긍정적 정서의 발달(Schneider et al., 2009; Williams et al., 2008), 학업 성취 및 뇌 기능 활성화를 포함한 인지적 발달(Castelli et al., 2014), 긍정적 관계 형성의 사회적 발달(Bailey, 2006) 등에 증거 기반 활동 (evidence based activity)으로 평가되고 있다. 이에 따 라, 서구 여러 국가의 건강당국에서는 청소년 신체활동 권장 기준을 일일 MVPA 60분으로 권고하고 있다 (CPPSE, 2013; PAGAC, 2008). 이러한 측면에서, 청 소년기 건강 교육의 핵심은 MVPA 증진에 있다.

청소년기 MVPA 특성을 보고한 연구들을 살펴보면, 첫째, 청소년기 MVPA는 조직적인 신체활동(예, 스포츠 활동) 참여에 비례한다. 예를 들어, 중·고등학교 학령기 청소년의 MVPA는 스포츠클럽 참여 유무 및 체육수업 등 록률에 영향을 받는다(CPPSE, 2013; NASPE, 2005). 둘째, MVPA가 주로 일어나는 생활 영역은 학교영역이 다. 국내 10 대 청소년의 $59.1 \%$ 는 학교 밖에서 조직적인 신체활동에 전혀 참여하지 않고 있다(MCST, 2012). 반 면, 생활영역별(학교영역, 여가영역, 집안일 영역, 교통 영역) 신체활동 비중을 보고한 연구들은 청소년 MVPA 의 학교영역 의존도가 높고, 강도가 높아질수록 그 의존 도가 크다고 밝히고 있다(Kang \& Lee, 2015; Lee \& Kang, 2015). 따라서, 청소년기 MVPA 증진 대안은 학 교체육 활동을 중심으로 이루어져야 한다.

체육수업은 청소년기 요구되는 일일 MVPA 권고량 충 족에 중요한 역할을 한다. 때문에, 미국체육교육당국은 체육수업 시간의 $50 \%$ 이상을 MVPA로 채울 것을 권고 하고 있다(NASPE, 2005). 그러나, 체육수업의 MVPA 수준은 기대만큼 높지 않다. 수업 운영의 주체, 성별, 수 업 내용 등에 따라 체육수업 MVPA 수준을 분석한 Fairclough \& Stratton(2005)은 체육수업의 MVPA 수 준을 8 47\%로 보고하고 있으며, 국내 연구에서도 신체 활동 증진 전략을 포함하지 않고 있는 체육수업의 MVPA 수준은 24.5 48.6\%로 나타나고 있다(Kang \& Lee, 2017; Lee \& Park, 2017; Lee et al., 2016; Lee, 2014). 이러한 측면에서, 학교체육 활동 특히 체육수업 의 MVPA 증진 방안에 관한 논의가 시도될 필요가 있다.

한편, 젠더(gender1))는 청소년기 신체활동의 주요한 결정요인이다(CPPSE, 2013). 즉, 남녀 청소년들은 단
지 젠더가 다르다는 이유로 상당한 신체활동 차이가 일어 날 가능성이 크다는 것이다. Trost \& Loprinzi(2008)에 따르면 일일 신체활동량 권고량을 달성하는 비율은 남학 생이 $44 \%$, 여학생이 $28 \%$ 로 나타나고 있으며, 체육수업 역시 남학생의 MVPA 비중(42 45\%)이 여학생 (30 36\%)을 압도한다(Fairclough, 2003; Fairclough $\&$ Stratton, 2005). 국내 체육수업 신체활동 수준을 분 석한 Lee(2019) 역시 젠더 차이를 $11.7 \%$ (남>여)로 보 고하고 있다. 무엇보다, 여학생의 MVPA는 학교영역에 대한 의존도가 상대적으로 더 크다(kang \& Lee, 2015). 이는 여학생 $\mathrm{MVPA}$ 의 상당량이 체육수업을 통해 제공된 다는 것을 의미한다. 이렇게 볼 때, 체육수업을 통한 여학 생 MVPA 증진에 관심을 기울일 필요가 있다.

SPARK(Sports, Play and Active Recreation for Kids) 프로그램은 대표적인 체육수업용 신체활동 증진 프로그램이다. 국내외 연구들을 통해, 이 프로그램은 체 육수업의 MVPA 증진에 효과적인 프로그램으로 인정받 고 있다(Dowda et al., 2005). 그러나 일부 연구(Lee \& Park, 2017)를 제외한 연구들에서는 MVPA 증진 효과 가 전체 학생과 남학생에 한정해 나타나고 있으며, 여학 생의 효과는 불확실한 것으로 보고되고 있다(Lee et al., 2014; McKenzie et al., 2004; Sallis et al., 1997). 프 로그램의 MVPA 증진 효과가 남학생에 의존해 나타나고 있는 것이다. 이에 대해, 신체활동 전문가들은 여학생의 신체활동 특성을 고려하지 않은 프로그램은 결국은 남학 생의 맞춤형 프로그램일 수밖에 없다고 비판해 왔다 (Dishman et al., 2004; Sallis et al., 1999). 이는 SPARK 프로그램은 체육수업의 신체활동 증진 전략 모 색에 시사하는 바가 크지만, 여학생 신체활동 특성을 고 려한 SPARK 프로그램의 수정 및 보완이 필요하다는 것 을 의미한다. 이에, 본 연구에서는 SPARK 프로그램 원 안에서 나타나는 여학생 신체활동 문제를 확인하고, 이를 수정·보완하는 연구를 수행하고자 한다.

체육과 교육과정 영역 중 학교 현장에서 평가 비중이 가장 높은 종목은 영역형 경쟁 스포츠인 축구이다(Lee

1) 젠더(gender)는 생물학적인 의미의 섹스(sex) 대신 사용되는 사회학적 개념의 용어로, 대등한 남녀 간의 관계를 내포한다. 이 연구가 학교의 현장개선연구임을 감안할 때 섹스보다 젠더 가 더 적합할 것으로 판단되어, 젠더로 표기하고자 한다. 
$\&$ huh, 2011). 평가 비중이 높다는 것은 공식적인 수업 내용으로 축구를 가장 많이 활용한다는 것이다. 또한, 축 구는 비공식적 수업 활동, 예를 들어, 기능 연습과 함께 제공되는 놀이용 게임 활동이나 학교 시험 이후 학생들의 놀이를 위해 제공되는 활동에서도 높은 비중을 차지하고 있다(Yun, 2000). 그러나, 여학생에게 축구는 가장 힘든 종목 중 하나로써, 이는 특유의 남성적 이미지와 색채가 강하고, 축구 경기를 수행하기 위해 요구되는 기능과 체 력 수준이 높기 때문이다(Quinn \& Strand, 1995). 여 학생들은 체육수업에서 공식적 및 비공식적으로 가장 빈 번하게 제공되는 축구 활동에서 적극적인 참여자가 될 수 없다. 실제로, 다른 종목들에 비해 성별 MVPA 격차(남> 여)가 심한 종목으로 나타나고 있다(Fairclough \& Stratton, 2005; Lee, 2019). 이러한 측면에서, 여학생 신체활동 증진 체육수업의 결과는 축구와 같이 젠더 불평 등 현상이 나타나는 종목을 통해 확인될 필요가 있다.

따라서, 본 연구에서는 SPARK 프로그램 원리에 따라 여학생 신체활동 증진 축구수업을 설계 및 실행하여 그 효과를 검증하고, 증진 요인을 확인하고자 한다. 이에 따 른 연구 문제는 다음과 같다.

1. SPARK 프로그램 원리에 따른 체육(축구)수업은 어떻게 개발되어야 하는가?

2. SPARK 기반 체육(축구)수업은 여학생 신체활동에 효과적인가?

2-1) SPARK 기반 체육(축구)수업은 여학생 신체활 동을 증진시키는가?

2-2) SPARK 기반 체육(축구)수업의 여학생 신체활 동 증진 요인은 무엇인가?

\section{연구방법}

\section{1. 연구설계}

본 연구는 Kemmis \& McTaggart(2000)의 비판적 실 행연구 전통에 따라 문제파악(1차 실행 및 반성), 문제해 결 계획(재계획), 실행 (2차 실행), 평가의 과정으로 진행 되었다. 구체적으로 살펴보면, 첫째, 문제파악 단계에서
는 SPARK 프로그램의 원안에 따라 계획된 축구 수업을 실행해 여학생 신체활동 문제를 파악하였다. 둘째, 문제 해결계획 단계에서는 확인된 문제에 대한 수정안을 개발 하였고, 셋째, 실행 단계에서는 수정안에 따라 수업을 실 행하였으며, 넷째, 평가 단계에서는 2 차 실행에 대한 자 료의 수집 및 분석을 통해 최종적인 평가가 이루어졌다.

1 차와 2 차 실행의 평가는 혼합연구 모형의 하나인 순 차적 설명 전략(sequential explanatory strategy)에 따 라 이루어졌다. 순차적 설명 전략은 양적 연구에서 나타 나는 차이를 질적 연구로 이해하는 혼합연구 접근으로 (Creswell, 2013), 본 연구에서는 3차원 가속도계를 활 용해 수업의 신체활동량을 측정 및 분석한 후, 질적 자료 를 수집 및 분석하여 차이의 이유를 살펴보았다.

\section{2. 연구과정}

\section{1) 연구대상}

수업은 1 차 실행과 2 차 실행으로 구분된다. 1 차 실행 은 2014년 10월 11월 실시되었고, 2차 실행은 다음 해 인 2015년 5월 6월에 실시되었다. 수업의 참여 대상 은 K중학교 1학년 학생들로 2014학년도 2학기에 담당한 6 개 학급 181 명 (남학생 109명, 여학생 72명)과 2015학 년도 1 학기에 담당한 6 개 학급 180 명 (남학생 110 명, 여 학생 70명)이었다.

먼저, 신체활동 측정 대상2)은 다음과 같이 선정되었 다. 신체활동량 측정은 1 차와 2 차 실행 각각 7 차시씩 12 명 (남학생 6명, 여학생 6명) 총 168명 (1차 84명, 2차 84 명)을 대상으로 실시되었다. 대상자는 임의 표집 방식으 로 선정하였으며, 측정 자료 중 기계 오류와 불성실한 착 용으로 인해 1 차 실행 1 명, 2 차 실행 3 명의 자료가 제외 되었다. 이에 따라, 각 실행별 측정대상은 각각 83명(남 42명, 여 41명), 81명 (남 41명, 여 40명)이었다. 대상의 특성은 〈Table 1〉에 정리되어 있다.

2) 본 연구는 여학생 신체활동량 증진에 주된 초점을 두고 있지 만 학급 자체가 혼성학급이며 이와 동시에 남학생과 여학생의 신체활동량 차이를 알아보기 위해 남학생과 여학생 모두의 신 체활동량을 측정함. 
Table 1. Characteristics of Participants

\begin{tabular}{ccccc}
\hline \hline Variable & $\begin{array}{c}\text { Male } \\
(\mathrm{n}=84)\end{array}$ & $\begin{array}{c}\text { Female } \\
(\mathrm{n}=84)\end{array}$ & $\begin{array}{c}\text { Total } \\
(\mathrm{n}=168)\end{array}$ \\
\hline Height & $\begin{array}{c}1 \mathrm{st} \\
\text { action }\end{array}$ & $\begin{array}{c}158.61 \pm 9.41 \\
(\mathrm{n}=42)\end{array}$ & $\begin{array}{c}156.33 \pm 6.37 \\
(\mathrm{n}=42)\end{array}$ & $\begin{array}{c}157.47 \pm 8 \\
(\mathrm{n}=84)\end{array}$ \\
\cline { 2 - 5 } & $\begin{array}{c}2 \mathrm{st} \\
\text { action }\end{array}$ & $\begin{array}{c}157.22 \pm 7.32 \\
(\mathrm{n}=42)\end{array}$ & $\begin{array}{c}157.44 \pm 5.16 \\
(\mathrm{n}=42)\end{array}$ & $\begin{array}{c}157.33 \pm 6.24 \\
(\mathrm{n}=84)\end{array}$ \\
\hline Weight & $\begin{array}{c}1 \mathrm{st} \\
\text { action }\end{array}$ & $\begin{array}{c}54.78 \pm 11.75 \\
(\mathrm{n}=42)\end{array}$ & $\begin{array}{c}46.28 \pm 8 \\
(\mathrm{n}=42)\end{array}$ & $\begin{array}{c}50.53 \pm 10.8 \\
(\mathrm{n}=84)\end{array}$ \\
\cline { 2 - 5 } BMI & $\begin{array}{c}51.06 \pm 11.79 \\
(\mathrm{n}=42)\end{array}$ & $\begin{array}{c}49.22 \pm 10.09 \\
(\mathrm{n}=42)\end{array}$ & $\begin{array}{c}50.14 \pm 10.85 \\
(\mathrm{n}=84)\end{array}$ \\
\hline action & $\begin{array}{c}1 \mathrm{st} \\
\text { action }\end{array}$ & $\begin{array}{c}21.52 \pm 2.75 \\
(\mathrm{n}=42)\end{array}$ & $\begin{array}{c}19.07 \pm 3.39 \\
(\mathrm{n}=42)\end{array}$ & $\begin{array}{c}20.29 \pm 3.29 \\
(\mathrm{n}=84)\end{array}$ \\
\cline { 2 - 5 } & $\begin{array}{c}2 \mathrm{n}=42 \\
\text { action }\end{array}$ & $\begin{array}{c}20.74 \pm 3.76 \\
(\mathrm{n}=42)\end{array}$ & $\begin{array}{c}19.87 \pm 4.39 \\
(\mathrm{n}=42)\end{array}$ & $\begin{array}{c}20.31 \pm 4.05 \\
(\mathrm{n}=84)\end{array}$ \\
\hline \hline
\end{tabular}

다음으로, 질적 연구 참여자들의 선정 과정을 살펴보 면, 체육교사로부터 체육수업이나 신체활동에 적극적인 여학생들과 그렇지 않은 여학생들을 소개받았다. 이들 중 첫째, 이 연구의 취지를 공감하고 유의미한 내용을 이야 기해 줄 수 있는 여학생, 둘째, 연구자와의 라포가 인터뷰 를 진행할 수 있을 만큼 충분히 형성된 여학생, 셋째, 연
구 참여에 동의한 여학생을 연구 참여 학생으로 선정하였 다. 최종적으로 1 차와 2 차 각 4 명의 여학생 (총 8 명)을 연 구 참여자로 삼았으며, 이들의 특성은 〈Table 2)와 같다.

또한, 수업 담당 교사인 $\mathrm{A}$ 교사를 보조 연구참여자로 선정하였다. A 교사는 6 년 차 남자 교사로 체육수업이 신 체적으로 활발하게 진행되고, 그 결과가 일상생활로 전이 되는 것이 체육교육의 가장 중요한 목표로 인식하고 있 다. 2014년 1급 정교사 연수에서 SPARK 프로그램을 처 음 접했으며, 이후 체력운동, 줄넘기, 농구, 축구, 육상 등의 단원에서 SPARK 프로그램을 적용하였고, 그 때마 다 학생들의 높은 신체활동 참여율에 고무되어 SPARK 프로그램의 옹호자가 되었다.

\section{2) 자료수집}

수업은 1 차 실행과 2 차 실행으로 구분된다. 1 차 실행 은 2014년 10월 11월 실시되었고, 2차 실행은 다음 해 인 2015년 5월 6월에 실시되었다. 수업의 참여 대상 은 K중학교 1학년 학생들로 2014학년도 2학기에 담당한 6 개 학급 181명 (남학생 109명, 여학생 72명)과 2015학 년도 1 학기에 담당한 6 개 학급 180 명 (남학생 110 명, 여 학생 70 명)이었다.

Table 2. Characteristics of Participants for Interviews

\begin{tabular}{|c|c|c|c|}
\hline Action & $\begin{array}{l}\text { Name } \\
\text { (Gender) }\end{array}$ & $\begin{array}{l}\text { Grade of } \\
\text { PAPS * }\end{array}$ & Physical Activity Characteristics and Features \\
\hline \multirow{4}{*}{$\begin{array}{c}1 \text { st } \\
\text { action }\end{array}$} & $\begin{array}{l}\text { Kang, S.B. } \\
\text { (female) }\end{array}$ & 2 & $\begin{array}{l}\text { Kang, S.B. is usually interested in health, has been practicing exercise since elementary school, active } \\
\text { in class }\end{array}$ \\
\hline & $\begin{array}{l}\text { Kim, Y.M. } \\
\text { (female) }\end{array}$ & 3 & Kim, Y.M. has no particular interest in physical activity, but participates hard in her favorite activities \\
\hline & $\begin{array}{l}\text { Lee, K.M. } \\
\text { (female) }\end{array}$ & 4 & $\begin{array}{l}\text { Lee, K.M. has poor health and is passive in physical education class, and especially hates activities } \\
\text { with the ball. }\end{array}$ \\
\hline & $\begin{array}{l}\text { Yang, H.B. } \\
\text { (female) }\end{array}$ & 3 & $\begin{array}{l}\text { Yang, H.B. has been taekwondo since childhood and is interested in physical activity, but his physical } \\
\text { strength is not good. }\end{array}$ \\
\hline \multirow{4}{*}{$\begin{array}{l}\text { 2nd } \\
\text { action }\end{array}$} & $\begin{array}{l}\text { Jung, G.R. } \\
\text { (female) }\end{array}$ & 5 & Jung G.R. has a poor physical ability but voluntarily participates in sports club activities. \\
\hline & $\begin{array}{l}\text { Jo, M.G. } \\
\text { (female) }\end{array}$ & 2 & $\begin{array}{l}\text { Jo, M.G. not only has a good physical fitness, but also likes all sports, active and active in sports } \\
\text { time. }\end{array}$ \\
\hline & $\begin{array}{l}\text { Choi, N.M. } \\
\text { (female) }\end{array}$ & 4 & $\begin{array}{l}\text { Choi, N.M. shows a high interest in learning for the first time but gives up easily because his physical } \\
\text { ability does not follow. }\end{array}$ \\
\hline & $\begin{array}{l}\text { Son, B.D. } \\
\text { (female) }\end{array}$ & 3 & $\begin{array}{l}\text { Son, B.D }>\text { does not have a particular interest in physical education classes, but because of his } \\
\text { relationship with teachers, he tries to participate in classes to some extent. }\end{array}$ \\
\hline
\end{tabular}

\footnotetext{
* PAPS: Physical Activity Promotion Sysetem, It is a physical fitness measurement system for Korean students.
} 


\section{(1) 3 차원 가속도계 $(\mathrm{GT} 3 \mathrm{X}){ }^{3)}$}

신체활동량 측정을 위해 ActiGraph사에서 개발된 3 차원 가속도계 (GT3X)를 활용하였다. 3차원 가속도계 는 기존에 사용되고 있는 신체활동량을 측정할 수 있는 도구들에 비해 간편하고 정확하며 다양한 정보를 제공해 주는 객관적인 신체활동 측정 도구이다(Tudor-Locke et al., 2011). 측정 과정을 살펴보면, 수업 전, 노트북 과 연결해 측정 시간을 미리 설정한 장비를 측정 대상자 들에게 나눠주고 허리에 착용하도록 하였다. 측정 시간 은 정규 수업 시간에 준하여 수업 시작에서 종료까지 45 분이었다. 가속도계 측정 시 요구되는 주의 사항(예, 물 에 닿지 않도록 하기, 임의로 풀지 않기 등)을 숙지시켰 으며, 수업이 종료된 이후 장비를 회수하여 자료를 추출 해 저장하였다.

\section{(2) 질적 자료 수집}

질적 자료는 수업 관찰, 수업 노트, 면담을 통해 수집 되었다. 첫째, 교사는 능동적인 참여 관찰자로, 수업의 전 체적인 진행과 학생들의 수업 시간의 모습들을 관찰 기록 으로 남겨 이를 관찰 자료로 활용하였다. 둘째, 학생들은 수업에서 경험한 것을 중심으로 수업 노트를 작성하였다. 수업 노트는 연구자가 수업을 진행하는 학생들을 대상으 로 주 1 회 총 5 회 이상 작성토록 하였다. 셋째, 면담은 4 명의 주요 연구참여 학생을 대상으로 이루어졌다. 면담은 점심시간 및 방과 후 시간을 이용하여 진행되었으며, 집 단 면담 1 회와 개별 학생의 개인 면담 2 회씩 이루어졌다. 면담 전 연구자는 수업 노트에 나온 내용을 분석해 반구 조화된 질문지를 구성하였다. 질문 과정에서 추가적으로 궁금한 것들에 대해 질문하였고, 녹음된 면담 내용은 면 담 당일에 전사하였다. 이 외에도 추가적인 자료는 비공 식적 면담을 통해 수시로 수집되었다.

\section{3) 자료분석}

본 연구에서는 Greene(2007)의 혼합연구 분석법(자 료 정리하기, 자료 줄이기, 자료 변형하기, 자료 관계 짓

3) 3 차원 가속도계는 기존에 신체활동량을 측정하는 도구인 보수 계, 심박수계에 비해 신뢰도가 높아 신체활동량 측정에 흔히 사용된다. 가속도계는 보통 허리에 벨트 형식으로 착용하며 내 장된 센서가 전후, 좌우, 상하의 3축의 움직임 정도를 파악하 여 신체활동량을 강도별로 기록하여준다.
기 및 비교하기, 연구결론 및 추론을 위한 분석)에 따라 수집된 자료를 분석하였다.

첫째, 자료 정리하기 단계에서는 양적 및 질적 자료의 개별적인 자료 분석이 이루어진다. 먼저, 양적 자료 분석 을 위해 3 차원 가속도계 측정 자료를 제조사인 ActiGraph사에서 제공하는 소프트프로그램(ActiLife v6.8.2)에 입력해 신체활동 강도별 시간 비중을 파악하 고, 엑셀 파일로 변환해 분석표를 만들었다. 분석 자료를 SPSS 22.0에 입력해 기술통계분석과 집단 간 비교(독립 t-test)를 실시하였다(〈.05). 다음으로, 질적 자료는 전 사, 코드화(의미 있는 내용을 분류), 범주화(분류된 코드 중 유사한 코드를 묶어 범주를 생성) 및 주제화(최종적인 주제를 생성)의 과정으로 분석되었다. 이들 분석 과정에 서는 개인을 중심으로 일어나는 신체활동의 영향요인들, 예를 들어, 개인 내적인 측면(심리적이며 동기적인 부분 들), 개인 외적인 측면(수업 과제나 내용 등의 외적 환경 적인 부분들), 개인 간 측면 (동료 학생들이나 교사들과의 관계적인 부분들)을 분석의 기준으로 삼았다. 최종적으 로 분석된 자료는 문서화하여 동료 평가(peer review)를 실시하였다.

둘째, 순차적 설명 전략의 경우, 양적 연구 결과의 차 이를 확인한 후 이를 확인하기 위한 과정에서 질적 연구 가 추가되기 때문에, 자료 줄이기와 변형하기 단계에서는 질적 자료에 대한 줄이기와 변형 작업이 이루어졌다. 질 적 자료 중 여학생 신체활동 문제와 관련 없는 것들이나 인식의 주요 흐름에서 이탈되어 있는 것들을 중심으로 자 료를 줄여 나갔으며, 필요한 경우, 내용 흐름에 따라 자료 를 변형하였다.

셋째, 자료 관계 짓기와 비교하기에서는 양적 자료와 질적 자료의 관계 설정과 이를 해석하는 작업이 실시되었 다. 통합적 분석에서는 양과 질의 자료들 간의 유사 관계 와 대립 관계들을 중점적으로 분석하지만, 이 연구에서는 연구방법들 간보다는 1 차와 2 차 실행 간에 나타나는 차 이를 중심으로 분석하였다. 이를테면, 1 차 실행과 2차 실 행 간 여학생의 MVPA 차이가 나타난 이유는 무엇인가를 질적 자료를 중심으로 살펴보며 양 실행 간에 나타나는 현상을 비교하였다. 분석의 예로, 1 차의 경우 단원 초기 동기 요인이 분명하지 않았던 반면, 2 차에서는 적극적인 신체활동에 대한 여학생의 필요성 인식이 상대적으로 뚜 
렷하게 나타났다. 이러한 분석 과정을 통해 1 차와 2 차의 결과들을 하나의 세트로 합시키는 작업이 이루어졌다.

넷째, 연구결론 및 추론을 위한 분석 단계에서는 이전 단계에서 분석된 자료들을 귀납적으로 발전시키고, 두 자 료를 혼합해 응집력 있는 주제들로 최종적으로 구성하는 작업을 수행하였다.

\section{3. 연구의 제한점 및 진실성}

본 연구는 교사 개인의 수업 개선을 위해 활용되는 실 행연구 모형을 바탕으로 진행된 연구이다. 때문에, 엄격 한 과학적 증명을 위해 통제된 환경이 아닌 수업의 자연 스러운 환경에서 얻은 결과를 바탕으로 한다. 이에 따라 연구 결과를 일반화하기에는 어렵다는 한계점을 갖고 있 다. 한편, 질적 자료의 정당성과 진실성을 확보하기 위해, 삼각검증법(triagulation)과 동료 평가(peer review)를 실시하였다. 자료 수집의 과정에서 참여관찰, 수업 노트, 면담의 3가지 경로로 자료를 수집하였고, 수업 설계부터 자료 분석 까지 동료 평가를 위한 협의회를 구성하였다. 협의회는 연구자를 포함한 스포츠 교육학 교수 1 명,
SPARK 프로그램 수업실천 경험이 있는 체육교사 1 명으 로 구성되었으며, 협의회는 구체적인 일정을 지정하여 모 든 구성원이 모여 논의하는 공식적인 회의를 총 3회 실시 하였고, 이메일이나 전화, 상시 만남을 통해 비공식적인 회의를 추가적으로 실시하였다.

\section{여학생 신체활동 증진 축구 수업 설계}

\section{SPARK 축구 수업 설계의 원리}

SPARK 프로그램은 체력 초점, 건강 댄스 초점, 스포 츠 초점 프로그램으로 구성돼 있다. 축구, 농구, 배구 등 의 스포츠 활동은 스포츠 초점 프로그램으로 제시되며, $\mathrm{A}$ 교사는 20 차시로 제시된 SPARK 축구 프로그램을 13 차시로 재구성해 1 차 실행 계획을 〈Table 3 〉와 같이 세웠 다. 1 차시 수업은 체육과 교육과정에 준해 축구의 이해를 목표로 $\mathrm{A}$ 교사가 임의로 포함한 것이다.

축구 수업의 각 차시는 SPARK 프로그램 매뉴얼 (Rosengard \& McKenzie, 2000)이 제공하는 네 가지

Table 3. 1st Soccer lesson plan

\begin{tabular}{|c|c|c|}
\hline Episode & Focus of class & Main activity \\
\hline 1 & $\begin{array}{l}\text { Understanding territorial competition and the } \\
\text { characteristics of football }\end{array}$ & Watch lectures and video \\
\hline 2 & Learn the concepts of dribbling and trapping & $\begin{array}{c}\text { Signal practice, dribbling as you walk, dribbling as you run, dribbling as you } \\
\text { turn, and trapping your soles }\end{array}$ \\
\hline 3 & $\begin{array}{l}\text { Learn the concept of the passing, } \\
\text { Quickly passing }\end{array}$ & $\begin{array}{l}\text { Inside Pass, Outside Pass, Change of Passing Foot, Moving Pass, Inside } \\
\text { Trapping }\end{array}$ \\
\hline 4 & \multirow{3}{*}{ Practice skills using games } & $\begin{array}{l}\text { Shadow dribbling, Soccer marble, Dribbling preservation game, } \\
\text { Give and run }\end{array}$ \\
\hline 5 & & Triangle path and stepping, group step back, 2-to-1 ownership game \\
\hline 6 & & Ball acquisition games \\
\hline 7 & \multirow{2}{*}{ Game skills practice using game } & \multirow{2}{*}{3 Trap Games } \\
\hline 8 & & \\
\hline 9 & \multirow{2}{*}{$\begin{array}{l}\text { Various methods of shooting, shooting } \\
\text { accuracy, throw-in posture practice }\end{array}$} & \multirow{2}{*}{ Shooting a goal with a sideline throw-in } \\
\hline 10 & & \\
\hline 11 & \multirow{2}{*}{$\begin{array}{l}\text { Application of competition skills through } \\
\text { transformation games }\end{array}$} & Small side soccer games \\
\hline 12 & & Soccer Baseball \\
\hline 13 & Try a full game of Soccer & Official soccer game \\
\hline
\end{tabular}


교수·학습 원리에 따라 설계되었다. 첫 번째는 성취의 원 리이다. 교사는 학습자 수준에 적절한 사이드 패스를 5 회 이상 연속해서 성공한 학생들은 뒤로 두 발 물러나 좀 더 긴 거리에서 인사이드 패스를 연습한다. 두 번째 원리는 효율성이다. 교사는 BASICS 전략4)에 따라 수업의 비활 동 시간을 줄이기 위해 노력한다. 셋째, 다양성의 원리이 다. 하나의 중심 활동으로 구성되는 전통적인 수업과 달 리, SPARK 수업에서는 스테이션 전략을 기반으로 다양 한 학습 활동이 수업시간 동안 운영된다. 넷째, 상호교수 전략이다. 축구는 성별이나 기능 차이에 따라 학습 조건 의 차이가 상당한 종목이기 때문에, 교사에 의한 직접 지 도의 한계가 있다. 이에 학습활동에서 학생들은 팀을 중 심으로 상호 교수하도록 요구받는다. 예를 들어, 기능 수 준이 높은 학생이 팀의 리더가 되고, 팀 내에서 상호 교수 가 이루어질 수 있도록 학습 활동은 파트너 활동으로 제 시되며, 이때 교사에 의해 제공되는 자료를 중심으로 상 호 교수자와 리더가 피드백을 제공한다.

\section{SPARK 축구 수업(1차 실행)의 문제 파악}

$\mathrm{A}$ 교사는 체육수업에서 활발한 신체활동이 필요하다고 굳건히 믿고 있다. 그는 신체활동 증진을 위해 스스로 여러 가지 방식을 적용해 왔지만 번번이 실패했다고 말한다.

여러 가지를 사용해 봤어요. 미국에서 발간한 체육수업 시간 에 사용할 수 있는 여러 가지 신체활동을 수업에 사용하기도 했는데, 그런 활동을 할 때는 잠깐 애들의 신체활동이 높아 진 것 같지만 금방 제자리로 돌아오더라고요. ...(중략)... 어떤 논문을 보고 만보계를 수업 시간에 활용하기도 했는데, 애들이 만보계가 신기했는지 처음에는 하나의 동기가 돼서 도움이 많이 됐는데 2-3주 정도 계속 하니까 조금 시들해 지더라고요(A 교사와의 면담).

$\mathrm{A}$ 교사는 조직적인 수업 프로그램의 필요성을 인식하 고 2014년부터 SPARK 프로그램을 수업에 적용하기 시작하였다.

SPARK 매뉴얼 북에 차시별 학습활동이나 전략 같은 것들

4) 수업의 비활동 시간을 줄이기 위해 사용하는 경계와 루틴의 설 정, 즉각적 활동, 설명시간의 압축, 적극적 감독 등의 활동을 말한다.
이 잘 나오는데 그것대로 하다보면 애들이 눈에 띠게 많이 움직인다는 게 느겨져요. 수업 중이나 후에 아이들과 이야기 하다보면 정말 많이 움직이고 있다는 이야기도 많이 듣고요.

지금은 거의 모든 수업에 SPARK 프로그램을 적용해요(A 교사와의 면담).

SPARK 프로그램 축구 매뉴얼에 따라 설계된 수업(1 차 실행)을 측정한 결과는 〈Table 4〉와 같다. 〈Table 4〉 를 살펴보면 수업의 평균 MVPA 비중은 약 $53 \%$ 정도로 나타났으며 이러한 결과는 NASPE(2004)에서 권고하고 있는 체육수업에서 달성해야 하는 신체활동 목표치인 수 업 대비 MVPA $50 \%$ 기준을 상회하는 결과이다. 또한 다 른 연구들에서 나타난 스포츠 활동의 MVPA 평균치가 45 52\% 정도인 점 (Fairclough \& Stratton, 2005)을 감안할 때 SPARK 축구 프로그램의 신체활동 성과는 긍 정적으로 평가할 수 있다.

Table 4. Physical activity level analysis (1st Action)

\begin{tabular}{cccc}
\hline \hline P.A. $*$ & Male & Female & Total \\
Level & $(\mathrm{N}=42)$ & $(\mathrm{N}=41)$ & $(\mathrm{N}=83)$ \\
\hline \multirow{2}{*}{ Inactivity } & 27.064 & 40.205 & 33.555 \\
& \pm 7.2425 & \pm 8.3119 & \pm 10.1793 \\
\hline \multirow{2}{*}{ Low } & 12.345 & 13.312 & 12.823 \\
& \pm 4.0030 & \pm 4.2713 & \pm 4.1410 \\
\hline \multirow{2}{*}{ Moderate } & 44.160 & 37.429 & 40.835 \\
& \pm 8.8405 & \pm 5.6990 & \pm 8.1474 \\
\hline \multirow{2}{*}{ Vigorus } & 13.043 & 7.839 & 10.472 \\
& \pm 5.2929 & \pm 4.0380 & \pm 5.3678 \\
\hline \multirow{2}{*}{ Very Vigorus } & 3.400 & 1.212 & 2.319 \\
& \pm 3.1310 & \pm 1.2598 & \pm 2.6243 \\
\hline \multirow{2}{*}{ MVPA } & 60.602 & 46.480 & 53.627 \\
& \pm 8.9758 & \pm 7.2275 & \pm 10.7806 \\
\hline \hline
\end{tabular}

* P.A. : Physical Activity

그러나 젠더별로 분석할 경우, 여학생의 비활동 시간 과 저강도 활동 시간은 높은 반면, 중강도 이상의 활동은 체육수업 신체활동 기준에 도달하지 못하는 것으로 나타 났다. 또한 표준 점수로 환산할 경우, 젠더 간 신체활동 참여 비중의 격차는 더 커지고 있다. 높은 강도의 활동은 질적으로 더 좋은 신체활동이라는 것을 의미한다. 이러한 측면에서, SPARK 축구 수업은 활발한 수업을 이끌어 내 
Table 5. Female physical activity problem diagnosis

\begin{tabular}{|c|c|c|c|}
\hline Physical & activity problem & Content summary & Improvement direction \\
\hline \multirow{2}{*}{$\begin{array}{l}\text { A class } \\
\text { without } \\
\text { motivation }\end{array}$} & $\begin{array}{l}\text { Absence of } \\
\text { meaning of physical } \\
\text { activity }\end{array}$ & $\begin{array}{l}\text { Female students believe that physical activity is necessary for } \\
\text { health and fitness, but in practice they disagree with the need } \\
\text { for physical activity, especially moderate to moderate intensity. }\end{array}$ & \multirow{2}{*}{$\begin{array}{l}\text { - Teaching health units in conjunction } \\
\text { with soccer units. } \\
\text {-Allows you to choose the difficulty } \\
\text { level of the assignment. }\end{array}$} \\
\hline & $\begin{array}{l}\text { Indifference and } \\
\text { rejection of Soccer }\end{array}$ & $\begin{array}{l}\text { Female students does not have much interest in soccer, but } \\
\text { rather prejudice that football belongs to male students }\end{array}$ & \\
\hline \multicolumn{2}{|c|}{ Physically burdened class } & $\begin{array}{l}\text { Experienced a physical burden in a SPARK soccer class that } \\
\text { requires active physical activity. }\end{array}$ & $\begin{array}{l}\text { There is a limit of two assignment } \\
\text { activities per class. }\end{array}$ \\
\hline \multirow{2}{*}{$\begin{array}{l}\text { Alienation } \\
\text { in class }\end{array}$} & $\begin{array}{l}\text { Correction } \\
\text { feedback-focused } \\
\text { class }\end{array}$ & $\begin{array}{l}\text { Interaction with the teacher is largely made of correctional } \\
\text { feedback and is mistaken for confusing correctional feedback. }\end{array}$ & \multirow{2}{*}{$\begin{array}{l}\cdot \text { Use emotional feedback-based } \\
\text { interaction strategies } \\
\text {-Equally direct male and female } \\
\text { learning activities. }\end{array}$} \\
\hline & Male-centered class & $\begin{array}{l}\text { Recognizes that teachers are not receiving attention because } \\
\text { they are primarily located in male student's activity spaces. }\end{array}$ & \\
\hline
\end{tabular}

지만, 여학생에게 MVPA를 충분히 제공하지 못한다는 문제를 갖고 있다.

\section{3. 문제 명료화 및 개선안}

여학생 신체활동 문제를 개선하기 위해 수업이 종료된 이후 교사 관찰 일지, 학생의 수업 노트, 그리고 연구 참 여 학생들과의 면담을 통해 여학생 신체활동 문제를 진단 하기 위한 자료를 수집하였다. 그 결과, 여학생의 신체활 동 문제는 크게 동기 없는 수업, 체력적으로 부담이 되는 수업, 소외되는 수업으로 확인되었다.〈Table 5) 각각의 문제를 살펴보면 다음과 같다.

첫째, 동기 없는 수업이다. SPARK 축구 프로그램은 신체활동량을 증진시키고 있지만, 여학생들에게 신체활 동이나 축구 참여에 대한 의미를 부여해 주고 있지는 않 았다. 이를테면, 남학생들은 축구에 대한 자발적 의지를 가지고 수업에 임하는 반면, 여학생들은 교사의 수업 운 영에 따라 성실히 참여할 뿐 상대적으로 수동적인 참여 동기를 가지고 있다는 것이다. 이런 점에서 많이 움직인 다는 것, 그리고 축구와 신체활동의 관계 등에 대한 동기 유발이 필요해 보인다. 이를 위해 다음과 같은 동기 전략 에 따라 수업을 재계획하였다.

신체적으로 활발한 수업에서의 참여 동기를 유발하기 위해서는 기본적으로 신체활동과 건강체력의 관계, 자신 의 체력 수준 확인, 실천 방안 마련 등의 학습이 도움이 된다(Kang \& Lee, 2017). 2015 체육과 교육과정은 건
강 단원을 하나의 단원보다는 다른 단원과 결합해 지속하 도록 권고하고 있다(ME, 2015). 이에, 단원 도입부에 건 강체력 단원을 포함해 운영함으로써 신체적으로 활발한 축구 수업의 의미를 부여하기 위해 노력하였다. 더불어, 자결성 이론에 따르면, 남학생에 비해 수동적일 수밖에 없는 여학생의 체육수업 태도는 스스로 과제를 선택할 수 있는 기회를 제공받을 때 능동적 태도로의 전환이 가능하 다(Dishman et al., 2004). 선택권을 가질 때 수업 태도 의 전환이 일어난다는 것이다. 여학생의 신체활동 증진 전략을 제안한 연구들은 여학생 선호 종목(내용 선택권) 을 제공할 것을 권고하나(Haerens et al., 2014; Sallis et al., 1999), 본 연구에서는 축구라는 종목이 결정된 상 태에서 여학생 신체활동 증진 전략을 모색하기 때문에, 내용 선택이 아닌 과제 난이도의 선택권을 부여함으로써 이 문제를 해결하고자 하였다. 이에, 하나의 과제에 여러 가지 기준을 제안해 여학생들 스스로 과제 난이도를 선택 할 수 있도록 하였다.

둘째, 체력적으로 부담되는 수업이다. 수업 노트에서 여학생들은 힘들지만 재미있다는 반응을 많이 보였다. 그 러나 면담 과정에서 수업의 차시 당 과제 활동이 불규칙 하고(차시 당 $1 \sim 4$ 가지 과제로 구성), 과제가 3개 이상일 경우 체력적 부담이 크고, 축구 기능을 충분히 연습할 수 없었다는 고충이 확인되었다. 여학생 조사를 통해, 하나 의 과제로 운영되는 수업에서는 지루함을 느끼고, 3 개 이 상의 과제로 운영되는 수업에서는 체력적 부담을 느낀다 는 점을 확인하였다. 이에 따라, 과제 활동을 2 가지 이하 
로 제한하는 것을 원칙으로 수업을 재계획하였다.

세 번째 문제는 소외되는 수업이다. 여학생들은 소외 의 원인을 교사와의 상호작용으로 지적하였다. 여학생 입 장에서 $\mathrm{A}$ 교사는 주로 남학생이 활동하는 공간에 있으며 남학생들과는 빈번한 상호작용을 하며 긍정적인 관계를 유지하는 반면, 자신들에게는 어쩌다 한번 오고 주로 실 수만을 지적한다고 비판하였다. SPARK 프로그램은 교 사와 학생 간 상호작용에 대한 지침을 명확히 제시하지 않고 있다. 그러나, 연구들에 따르면, 여학생들은 남학생 들에 비해 교사와의 상호작용 빈도나 방식에 의해 영향을 크게 받는다(Sallis et al., 1997). 특히, 사회적 정서 교 육론자들은 교정적 피드백 비중이 높은 수업은 여학생에 게 반감을 가지게 할 가능성이 크다고 지적하며, 정서를 중시하는 여학생에게는 '선 공감 후 교정'의 정서적 피드 백 접근이 필요하다고 강조한다(Merrell \& Gueldner,
2010). 즉, 정서에 대한 공감을 시작으로 필요한 내용의 교정이 이루어지는 것이 여학생의 수업 태도에 긍정적이 라는 것이다. 이에, 정서적 피드백을 중심으로 상호작용 전략을 구성하여 소외되는 수업 문제를 개선하고자 하였다.

이상의 세 가지 전략을 바탕으로 기존의 SPARK 축구 수업을 수정해 〈Table 6)과 같이 2차 실행을 재계획하였 다. 재계획된 수업을 2015년 5월 4일부터 6월 5일까지 진행하였으며, 매 차시 수업은 동일한 수업 루틴(즉각적 활동을 통한 준비운동, 출결확인 및 환자파악, 수업 목표 제시, 수업 과제 제시, 과제 연습, 형성 평가, 수업의 정 리, 다음 차시 예고)에 따라 운영되었고, 교사는 도입 7 분, 전개 33 분, 정리 5 분의 시간을 정확히 지키고자 노력 하였으며, 이를 위해 압축된 목표와 과제 제시 활동을 수 행하였다.

Table 6. 2nd Soccer lesson plan

\begin{tabular}{|c|c|c|c|}
\hline Unit & Episode & Focus of Class & Main Activity \\
\hline \multirow{3}{*}{$\begin{array}{l}\text { Health } \\
\text { (Motive) }\end{array}$} & 1 & $\begin{array}{c}\text { The concept of health fitness and the importance of } \\
\text { physical activity, Relationship between physical fitness } \\
\text { and physical activity }\end{array}$ & $\begin{array}{c}\text { Lectures on PPT(health fitness), Watch videos(Physical } \\
\text { activity and health), Writing(Commitment to improve } \\
\text { health) }\end{array}$ \\
\hline & 2 & \multirow{2}{*}{ Health fitness measurement and diagnosis } & \multirow{2}{*}{$\begin{array}{l}\text { PAPS measurement(shuttle run, BMI, long jump), } \\
\text { health fitness diagnosis(checking fitness level), } \\
\text { Create exercise plan }\end{array}$} \\
\hline & 3 & & \\
\hline \multirow{13}{*}{ Soccer } & 1 & $\begin{array}{l}\text { Understanding territorial competition and the } \\
\text { characteristics of soccer, including health effects }\end{array}$ & lectures and Watch the video \\
\hline & 2 & $\begin{array}{l}\text { Try to trap the soles without mistakes } \\
\text { When dribbling, don't let the ball fall more than 1-2 } \\
\text { meters away }\end{array}$ & Dribbling while walking, Dribbling while running \\
\hline & 3 & \multirow{2}{*}{ Try the game with learned trapping and dribbling } & Shadow dribble, Dribble ownership game \\
\hline & 4 & & Ball acquisition games, Ball collecting games \\
\hline & 5 & $\begin{array}{l}\text { Give and take balls using multiple passes (inside, } \\
\text { outside, instep) and trapping (sole, inside, legs) }\end{array}$ & $\begin{array}{l}\text { Various passes and trapping exercises, } \\
\text { Run with a pass }\end{array}$ \\
\hline & 6 & \multirow{3}{*}{ Try a game with pass and trapping } & Group Step Back, Two-to-One Ownership Game \\
\hline & 7 & & Pass \& Follow, Corner to Corner Pass \& Go \\
\hline & 8 & & 3 Trap Games, 3 to 1 Pass Game \\
\hline & 9 & $\begin{array}{l}\text { Send the ball exactly to the designated area with an } \\
\text { inside kick, Send the ball away with an instep kick }\end{array}$ & Target Soccer, Kick Away \\
\hline & 10 & $\begin{array}{l}\text { Understanding the throw-in tricks, try the } \\
\text { transformation game }\end{array}$ & Throw-in practice, Three-to-three game \\
\hline & 11 & \multirow[b]{2}{*}{ Try transform game } & Small side soccer games \\
\hline & 12 & & $\begin{array}{c}\text { Soccer baseball, } \\
\text { Match with two soccer balls }\end{array}$ \\
\hline & 13 & Try a full game of Soccer & Official soccer game \\
\hline
\end{tabular}




\section{실행 결과}

\section{1. 양적 연구: 체육수업 신체활동 비교·분석}

2 차 실행에 나타난 신체활동 수준의 기술분석 결과는 〈Table 7〉과 같다.

1 차 실행과 비교할 때, 2 차 실행의 강도별 신체활동 비 중은 비활동 $(33.6 \% \rightarrow 28.8 \%)$ 과 저강도 활동 $(12.8 \% \rightarrow$ $11.6 \%)$ 에서 감소한 반면, 중강도 $(40.8 \% \rightarrow 45.2 \%)$, 고 강도 $(10.5 \% \rightarrow 12.1 \%)$, 매우 고강도 활동 $(2.3 \% \rightarrow$ $2.5 \%)$ 에서 증가하였다. 남녀에 따라 비교하면, 남학생의 매우 고강도 활동 비중이 감소한 것을 제외하면, 남녀 학 생 모두 전체 학생과 유사한 결과를 보이고 있다. 또한 여 학생의 2차 실행 MVPA 비중은 체육수업 MVPA 권장 기 준(수업 대비 $50 \%$ 이상)을 상회하는 것으로 나타났으며, 〈Table 8〉에서 보는 바와 같이, 여학생의 실행 간 MVPA 비중 차이는 통계적으로 유의미한 것으로 나타났다. 따라 서, 재계획된 SPARK 축구수업(2차 실행)은 MVPA를 포함한 남녀 학생 모두의 신체활동을 증진시켰다.

\section{2. 질적 연구: 여학생 신체활동 증진 요인}

재계획된 축구 수업(2차 실행)의 어떤 요인이 여학생 신체활동 증진에 기여하였는가? 연구 결과를 분석한 결 과, 그 이유는 다음의 세 가지로 확인되었다.

Table 7. Physical Activity Level Analysis (2nd Action) Unit: \%

\begin{tabular}{cccc}
\hline \hline $\begin{array}{c}\text { P.A. } \\
\text { Level }\end{array}$ & $\begin{array}{c}\text { Male } \\
(\mathrm{N}=41)\end{array}$ & $\begin{array}{c}\text { Female } \\
(\mathrm{N}=40)\end{array}$ & $\begin{array}{c}\text { Total } \\
(\mathrm{N}=81)\end{array}$ \\
\hline \multirow{2}{*}{ Inactivity } & 25.493 & 32.093 & 28.752 \\
& \pm 9.1479 & \pm 9.9411 & \pm 10.0520 \\
\hline \multirow{2}{*}{ Low } & 11.032 & 12.163 & 11.590 \\
& \pm 3.8088 & \pm 3.3863 & \pm 3.6287 \\
\hline \multirow{2}{*}{ Moderate } & 46.276 & 44.015 & 45.159 \\
& \pm 10.6293 & \pm 7.9048 & \pm 9.3939 \\
\hline \multirow{2}{*}{ Vigorus } & 14.112 & 9.950 & 12.057 \\
& \pm 6.2061 & \pm 5.0794 & \pm 6.0183 \\
\hline \multirow{2}{*}{ Very } & 3.107 & 1.785 & 2.454 \\
Vigorus & \pm 2.5991 & \pm 1.4956 & \pm 2.2160 \\
\hline \multirow{2}{*}{ MVPA } & 63.495 & 55.750 & 59.670 \\
& \pm 9.1329 & \pm 10.1017 & \pm 10.3263 \\
\hline \hline
\end{tabular}

1) 수업 초기 이루어진 '자발'적 동기 유발

2 차 실행 역시 1 차와 마찬가지로 수업에서 여학생들의 적극적인 활동이 관찰되었다.

이번 축구 수업은 지난번 축구 수업과 마찬가지로 학생들의 움직임은 활발하다. 학생들과의 수업시간이 무척이나 즐겁 다(2차 실행, 4 차시 $A$ 교사의 관찰일지).

그러나, 1 차에서의 활발한 신체활동은 수동적인 참여 라는 한계가 있었다.

음... 축구를 왜 해야 하는지도 잘 모르겠고요. 움직이는 것 자체가 귀찮기도 해요. 선생님께서 하라고 해서 하긴 하는 것 같은데 제가 좋아서나 필요해서 하는 것 같지 않아요(이 강물 학생과의 면담).

1 차 실행 당시 학생들이 수동적으로 수업에 참여하는 모습은 단원 초에 집중되었다. 이강물(위)이나 A 교사 의 면담(아래)에서 보듯이, 이는 남학생과 달리, 여학생 들의 경우 축구 수업에 참여해야 하는 이유를 찾지 못했 기 때문으로 판단된다.

남자 애들은 축구가 좋으니까 많이 움직이게 설계된 축구 연 습활동에 열심히 참여했던 것 같아요. 하지만, 여자 애들은 그렇지 않잖아요. 축구에 대해서 그렇게 좋은 마음을 가진 것도 아니고, 그렇다고 왜 신체활동을 열심히 해야 하는지도 잘 모르고요. ...(중략)... 1차 실행을 돌아볼 때, 수업 초반

Table 8. Comparison of MVPA between groups (1st vs 2nd) Unit: \%

\begin{tabular}{|c|c|c|c|c|c|}
\hline Gender & $\begin{array}{l}\text { Action } \\
(\mathrm{N})\end{array}$ & $\operatorname{MVPA}(\mathrm{M} \pm \mathrm{SD})$ & $\mathrm{t}$ & $\mathrm{df}$ & $\mathrm{p}$ \\
\hline \multirow{2}{*}{ Male } & $\begin{array}{c}\text { 1st action } \\
(\mathrm{n}=42)\end{array}$ & $60.602 \pm 8.9758$ & \multirow{2}{*}{1.455} & \multirow{2}{*}{81} & \multirow{2}{*}{.149} \\
\hline & $\begin{array}{c}\text { 2nd action } \\
(\mathrm{n}=41)\end{array}$ & $63.495 \pm 9.1329$ & & & \\
\hline \multirow{2}{*}{ Female } & $\begin{array}{c}\text { 1st action } \\
(\mathrm{n}=41)\end{array}$ & $46.480 \pm 7.2275$ & \multirow{2}{*}{4.759} & \multirow{2}{*}{79} & \multirow{2}{*}{$.000 * *$} \\
\hline & $\begin{array}{l}\text { 2nd action } \\
\quad(\mathrm{n}=40)\end{array}$ & $55.750 \pm 10.1017$ & & & \\
\hline \multirow{2}{*}{ Total } & $\begin{array}{c}\text { 1st action } \\
(\mathrm{n}=83)\end{array}$ & $53.627 \pm 10.7806$ & \multirow{2}{*}{3.665} & \multirow{2}{*}{162} & \multirow{2}{*}{$.000 * *$} \\
\hline & $\begin{array}{l}\text { 2nd action } \\
\qquad(\mathrm{n}=81)\end{array}$ & $59.670 \pm 10.3263$ & & & \\
\hline
\end{tabular}


이 어려웠던 것 같아요. 수업이 중간 정도 되면 힘들어도 수 업에서 재미있는 것들을 아이들이 찾아서 그것으로 힘을 내 는데, 초반에는 그런 게 거의 없잖아요. 그러니까 내가 그냥 시키니까 하게 되는 것 같았어요(A 교사와의 면담).

반면, 2차 실행에서는 동기 유발 수업으로 건강 단원 수업을 실시하였다. 건강 단원에서는 건강과 신체활동 단 원의 교과내용을 중심으로 실시하되, 건강체력과 신체활 동의 관계를 설명할 때 이어서 수업할 축구의 건강 특성 을 부각시켰다. 최냇물의 이야기처럼 건강과 축구의 관계 에 대한 설명으로 시작한 수업은 축구에 대한 필요성을 인지시키는 역할을 하였다.

\section{남자 애들한테는 축구가 재미있는 거잖아요. 저희들한테 축 구는 별로 재미있는 게 아니거든요. 개네들처럼 할 맘이 잘 안 드는 거죠. 처음에는 좋아서 라기 보다 건강하기 위해 필 요한 거니까 축구를 배우면 좋겠다 이렇게 생각했어요(최냇 물 학생과의 면담).}

건강 단원과 연계한 수업은 여학생들이 가지고 있는 건강에 대한 오개념, 대표적으로, '건강한 몸 =날씬한 몸' 이나 '날씬한 몸을 위해서는 식단 조절이 최고' 등의 오개 념(Kang \& Lee, 2017)을 불식시키는 역할을 하였으며, 이어진 PAPS 측정 결과는 여학생의 건강체력 상태를 직 면할 수 있는 기회를 주었다. 체력 등급(5등급)이 낮은 정가람 학생의 인터뷰에서 보듯이, 이것은 신체활동 동기 를 자연스럽게 높이는 역할을 하였다.

축구 전에 건강체력 결과를 보고 충격을 받았어요. 건강이 중요하다는 것도 알았어요. 그래서 축구 수업시간에 자연스 럽게 열심히 하게 되더라고요(정가람 학생과의 면담).

건강을 위해 운동해야 한다는 당위적 설명만으로는 여 학생의 신체활동 참여를 이끌어내지 못한다. 여학생의 자 발적 신체활동을 이끌어 내기 위해서는 알고 있는 당위가 실제에서 체험되어야 한다(Kang \& Lee, 2017). 조물결 의 수업노트나 교사의 관찰일지는 아는 것을 경험으로 체 득될 때 신체활동 참여 동기로 이어진다는 것을 보여준 다.

오늘도 지난 시간처럼 패스 연습을 하는 날이었다. (지난번 에) 너무 힘들어서 오늘 너무 하기 싫었고, 오늘은 그때보다
더 넓게 서서 운동장을 가로지르며 패스 주고받기를 했는데, 저번 보다 덜 힘들다. 하도 운동을 안 해서 한번 해도 체력이 막 좋아지는 것 같다. 하하 안 힘들어서 좋고, 다음에 더 안 힘들 것 같아 좋다(조물결 학생의 수업노트).

오늘은 살이 많이 찐 상민이가 나에게 와서 "쌤 땀나니까 살 빠지는 것 같아 좋아요. 앞으로 더 열심히 할게요.” 라며 나 를 보고 웃고 같다(2차 실행, 4차시 $\mathrm{A}$ 교사의 관찰일지).

한편, 축구 단원의 첫 번째 수업에서 $\mathrm{A}$ 교사는 축구의 전반적인 이해를 돕는 동영상을 지소현 축구 영상으로 준 비해 보여주었다. 손바다의 이야기처럼, 여학생들은 여 자축구선수 영상을 통해 축구에 대한 편견을 조금은 버릴 수 있었다.

지소현 완전 멋있었어요. 여자 축구가 있다는 것도 처음 알 았는데, 지소현처럼 해외에서 뛰고 정말 잘하는 선수가 있는 줄도 몰랐어요. ...(중략)... 남자 애들이나 하는 건 줄 알았 는데, 여자들도 잘 할 수 있다는 걸 알 수 있어서 그렇게 거 부감이 생기거나 하지는 않았어요(손바다 학생과의 면담).

2차 실행에서는 단원 초 계획된 수업 활동들을 통해 여 학생의 신체활동 필요성 인식과 젠더 편견 불식이 나타났 다. 신체활동 필요성 인식은 활발한 신체활동의 실제적 체험으로 이어지며 할 수 있다는 자신감으로, 젠더 편견 의 불식은 '여자인 나도 축구를 해도 되는구나!'와 같은 활 동의 접근 가능성 (accessibility)으로 이어졌다. 연구들 에 따르면, 신체활동에 대한 자신감은 신체활동 참여의 주요한 요인(Stuntz \& Weiss, 2010)이자 중단의 요인 이기도 하며(Slater \& Tiggemann, 2010), 젠더 편견 (여자가 축구를?)은 여학생의 축구와 같은 남성 젠더적 인 스포츠 활동 참여를 제약하는 요인으로 작용한다 (Slater \& Tiggemann, 2010). 이러한 측면에서, 수업 초기의 여학생 동기를 증진시키기 위한 전략은 2 차 실행 의 여학생 신체활동을 증진 주요 전략이라 할 수 있다.

\section{2) 힘들어도 '의미'있는 학습 활동}

1 차 실행에서 여학생들은 SPARK 프로그램이 제공하 는 다양하고 활동적인 학습활동에 참여하면서, 힘들지만 재미있게 수업을 경험하였다. 김연못 면담이나 강수변의 수업 노트를 통해 힘들지만 재미있다는 여학생의 경험을 확인할 수 있다. 
축구 수업 시간동안 많은 활동을 했었는데요. 솔직히 힘들었 지만 재미있었어요. 생각보다 재미있는 활동이 많아서 그런 것 같아요(김연못 학생과의 면담).

쉐도우 드리블은 내가 할 때는 신이 나고 재미있었는데 다른 사람을 따라 하려니 이리저리 뛰면서 따라가느라 정말 힘들 었다(강수변 학생의 수업노트).

그러나, 강수변의 수업노트에서 보듯이 여학생들은 힘 들다는 표현을 많이 하였다. 특히 1차 실행에서는 과제의 수가 많은 수업에 대해 체력적 부담을 호소하는 여학생들 이 많았다. 이에, 2 차 실행에서는 여학생의 참여가 높았 던 활동을 중심으로 차시 당 과제를 최대 2 가지로 적정화 하였다. 그 결과, 2 차 실행에서 과제 수나 양으로 인해 체 력적 부담을 호소하는 여학생들은 없었다.

한편, 김연못이나 강수변의 이야기에서처럼, 1 차 실행 의 결과에서는 재미를 강조하는 모습이 눈에 띄게 나타났 다. 이를테면, 여학생들은 힘들어도 재미있어서 열심히 한다는 것이다. 반면 2 차 실행에서는 '의미'에 대한 경험 적 이야기가 많이 나타났다. 연구참여학생들의 자료를 분 석한 결과, 의미는 다음의 세 가지 측면에서 나타나고 있다.

첫째, 여학생들은 축구 자체에 의미를 부여하고 있다. 1 차 실행에서 여학생들은 축구는 남자애들만 좋아하고 그래서 남학생들만 하는 것으로 규정하는 경향이 있었다. 또한 자신들은 남학생들 수업을 구경하는 관중으로 규정 하기도 하였다.

축구는 남자애들이 하는 것이다. 초등학교 때도 축구를 배웠 지만 내가 하는 것보다 남자애들 구경하는 게 더 좋았다(양 해변 학생의 수업노트).

그러나 2 차 실행에 참여한 여학생들은 축구의 여러 가 지 매력에 공감하였다. 대표적으로, 조물결의 면담에서 축구의 매력은 경기로써 축구로, 정가람의 수업노트에서 는 팀으로써 축구로 그 매력이 설명되고 있다.

예전에 TV를 보면 축구 선수들이 한골을 넣고 엄청 좋아하 잖아요? 저는 그것을 이해를 못했어요. 왜 저러지? 저렇게 기분이 좋나? 그런데 축구를 배우면서 특히, 시합할 때요. 제가 골을 넣었는데 진짜 기분이 좋았어요. 나도 할 수 있구 나 이런 생각도 들구요. 이젠 골을 넣고 왜 좋아하는지 알겠 어요. 축구 수업시간에 종종 잘 안 되는 게 있어 솔직히 짜증
도 많이 나고 축구가 싫었어요. 그런데 이젠 그런 거 없고 축구가 너무 좋아요. 또 시합하고 싶어요(조물결 학생과의 면담).

오늘 축구 시합을 하면서 우리 팀이 골을 넣었다. 우리팀도 할 수 있구나 하는 생각이 들었고 골을 넣은 수정이가 정말 멋져 보였다. 난 이제 축구가 좋다(정가람 학생의 수업노트).

둘째, 여학생들은 기능 성취에서 의미를 찾고 있다. 손 사용이 금지되는 축구 수업에서 초보자인 여학생들은 기 능 연습 과정에서 성공 경험보다는 좌절 경험을 많이 한 다. 반면, 최냇물의 면담 내용에서 보듯이, 2 차 실행에서 여학생들은 축구 기능 연습에서 성공 경험을 이야기하고 있다.

드리블이나 패스, 슛 연습할 때 제가 좌절감을 느낀 적이 한 번 도 없었어요. 그냥 수업 하다보면 나도 성공할 수 있구나. 체육 시간이 어렵지 않구나 하는 생각이 많이 들었어요. 체 육을 배우면서 어렵지 않게 배우는 건 거의 처음 인 것 같아 요(최냇물 학생과의 면담).

물론 1차 실행의 인터뷰나 수업 노트에서도 성공 경험 이 나타나고 있다. 이강물의 수업 노트에서 보듯이, 1 차 실행의 성공 경험은 여학생 수준에서 성공 가능한 과제 즉 난이도 낮은 과제에서 경험되었다.

이번 주 내가 배운 축구 수업시간 가장 기억에 남는 것은 쉐 도우 드리블이다. 쉐도우 드리블을 할 때 내가 실제로 드리 블을 잘 못해도 내 앞사람이 드리블하는 것을 잘 보고 공 없 이 따라 하기만 하면 성공이다. 나도 체육시간에 잘 할 수 있다(이강물 학생의 수업노트).

그러나, 1 차 실행에서는 최냇물 학생처럼 운동 능력 특히 공을 다루는 능력이 현저히 떨어지는 학생의 성취 경험에 대한 이야기는 거의 없었다. 이렇게 낮은 능력을 갖고 있는 여학생조차 좌절이 없었다고 말하는 것은 2 차 실행에서 학생 스스로 과제 난이도를 조절할 수 있도록 기회를 부여했기 때문으로 판단된다. 이는 그녀와의 이어 지는 대화를 통해서 확인된다.

연구자: 정말? 한 번도 좌절한 적이 없었어? 좌절해 본 적이 없는 건 어렵지 않아서 그런 거야?

최냇물: 어렵지 않은 것보다 제가 할 수 있는 걸 제가 선택 
해서 연습해서 인 것 같아요.

연구자: 그렇게 되면 수업에 더 열심히 하게 돼?

최냇물: 네. 제가 할 수 있는 걸 제가 결정하니까 할 수 있도 록 더 열심히 하게 되잖아요.

특이하게도 여학생들은 자신의 성공뿐만 아니라 동료 학생의 성공에 함께 성공의 의미를 부여하는 모습도 나타 난다.

친구들과 3 트랩 게임인가 그거 할 때요. 뭔가 내가 성공하는 것 보다 같이 연습하는 친구가 성공 하는 게 더 기쁠 때가 있었어요(손바다 학생과의 면담).

셋째, 학생들은 힘든 것을 이겨냈다는 자부심에 의미 를 부여하기도 한다.

축구 베이스볼은 정말 1 바퀴만 뛰어도 숨이 차서 많이 힘들 어요. 한 게임하면 몇 바퀴 돌고 그러면 죽을 것 같은데, 그 런데 이상하게 죽어라 힘들지 만은 않아요. 재미있기도 하 고, 제가 그걸 해냈다는 생각이 더 많이 들거든요(조물결 학 생과의 면담).

쉐도우 드리블과 소유권 유지게임을 했는데 힘들기도 했지 만, 운동하고 난 다음에 쪽 흘린 땀을 닦고 나면 뿌듯해진다. 이래서 사람들이 축구하는 것 같다(정가람 학생의 수업노트).

2차 실행에서 여학생들은 체력적으로 힘든 축구수업 을 '재미'와 '의미'라는 경험으로 이겨나가고 있다. 재미가 활동 과정에서 경험하는 심리적 만족감이라면 의미는 목 표 달성을 통해 이루어진다(You, 2002). 청소년 신체활 동 상관 요인을 메타 분석한 Stuntz \& Weiss(2010)는 신체활동 재미와 성취감을 통해 향상되는 자신감, 자율성 등이 신체활동 참여를 결정하는 가장 주요한 심리적 요인 으로 밝히고 있다. 연구 참여 학생들 역시 축구의 매력, 기능의 성취, 그리고 체력적 한계에 대한 도전 등을 경험 하며, 체육수업의 재미와 의미를 발견하고, 보다 적극적 인 신체활동에 참여하고 있다. 이런 점에서, 재미와 성취 를 통한 의미를 제공하는 학습 경험은 2 차 실행의 효과를 견인한 또 다른 요인이라 할 수 있다.

\section{3) '친절'한 체육교사}

$\mathrm{SPARK}$ 프로그램은 학생들 간의 활발한 상호작용을
강조한다. 여학생의 경우, 상대적으로 학생 간 상호작용 을 활동의 재미 요소로 인식하는 경향이 크기 때문에, 활 발한 상호작용은 여학생 신체활동을 증진시키는 SPARK 프로그램의 강점으로 평가되어 왔다(Lee, 2014; Lee et al., 2014). 때문에, 1, 2차 실행 모두에서 학생들 간의 활발한 상호작용은 적극적인 신체활동 참여의 주요한 동 인으로 작용하였다.

김연못 : 사실 체력적으로 좀 힘들 긴 했어요. 체육 시간에 이렇게 움직이긴 처음이니까요.

연구자 : 그런데 너희들이 쓴 수업노트에는 힘든데 재미있 다는 표현도 많던데? 혹시 수업에서 재미있게 해 주는 것들이 어떤 것들인지 말해줄 수 있니?...(중 략)...

양해변 : 맞아요. 많이 움직이고 하면 힘들 기도 한데, 힘들 즈음에 다른 활동하니까 덜 힘들었던 거 같고요. 혼자만 하는 게 아니니까 할 만 하고요. 같이 하면 서 서로 이야기도 해 주니까 힘들어도 재밌는 것 같 아요...(중략)...

강수변 : 저도 그렇게 생각해요. 체육수업 할 때 거의 함께 했는데 그게 제일 힘낼 수 있게 만들어 줬던 것 같 아요.

위의 대화는 1 차 실행 종료 후 실시한 그룹 면담 내용 의 일부이다. 전문을 다 제시하고 있지 않지만, 힘들어도 재미있게 수업에 참여할 수 있었던 이유에 대해, 여학생 들은 다양하게 운영되는 연습활동, 성공 경험, 그리고 학 생 간 상호작용 등으로 밝히고 있다. 그 중 다른 요인들에 비해 학생 간 상호작용 요인은 거의 모든 연구 참여 학생 들의 지지를 받았다.

2차 실행 과정에서 학생 간의 활발한 상호작용이 나타 났다. 그러나 1 차 실행과 다른 부분은 교사와의 상호작용 측면이었다. 이는 1 차 실행에서 지적된 교정적 피드백 중 심의 상호작용에 대한 대안으로 계획된 정서적 피드백 중 심 상호작용 전략의 실천 덕분으로 판단된다. 이를 구체 적으로 살펴보면 다음과 같다.

처음 선생님을 만나고 학기 초에 청소년 체조를 배울 때만 해도 선생님과 별로 안 친하고 해서 수업도 별로였어요. 사 실, 청소년 체조가 지겹기도 했지만 선생님이 다가가기 어렵 고 해서 더 그랬던 것 같아요. 그런데 축구 수업을 하면서 선생님과 많이 가까워 진 것 같아요. 특별히, 가까워질만한 어떤 것을 한 것은 아닌데... 생각해보면 그냥 선생님께서 
잘하고 못하고 이런 말보다는 열심히 했다 더 열심히 움직이 자 이런 말씀을 많이 해 주셔서 그런가 봐요(최냇물 학생과 의 면담).

축구 수업 하면서 친구들끼리도 친해졌지만 선생님과도 친 해진 것 같아요. 우리를 많이 생각해 주신다는 느낌? 선생님 께서 항상 많이 움직이자고 잘하고 있다고 격려를 많이 해주 세요. 선생님이 잘 해 주시니까 축구 수업도 좋아지고요(손 바다 학생과의 면담).

최냇물이나 손바다 학생은 2 차 실행에서 교사와 친밀 해진 이유가 정서적 지지에 있다고 말하고 있다. 또한 두 명의 이야기에서 공통적으로 나타나는 것은 선생님에 대 한 인상이 수업에 대한 태도에 영향을 미치고 있다는 것 이다.

수림이가 수업 끝나고 나한테 달려와서는 "지난 번 3트랩 게임 수업 때 열심히 하는 모습을 보여주지 못해서 죄송했어 요." 라며, 그래서 오늘은 좀 몸이 안 좋았지만 열심히 뛰었 다고 말한다. 체조 수업 할 때는 아랑곳하지 않더니 이번 수 업에서 친해진 다음에는 내 마음도 알아주는 것 같다(2차 실 행, 9 차시 $A$ 교사의 관찰일지).

$\mathrm{A}$ 교사의 관찰일지에서 보는 것과 같이, 교사에 대한 긍정적 관계 개선은 힘든 신체활동에도 열심히 참여하게 하는 이유로 작용하고 있다.

관계성 (relatedness)은 심리적 요인(즐거움, 효능감, 자율성)과 함께 청소년 신체활동의 결정적인 사회적 요 인이다(Stuntz \& Weiss, 2010). 여학생의 경우, 심리적 요인(예, 즐거움, 효능감 등)에 반응하는 남학생들에 비 해 사회적 관계 요인이 상대적으로 더 크게 작용한다 (Sallis et al., 1999). 이런 점에서, 동료학생들과의 활 발한 상호작용 전략은 여학생 신체활동 증진에 주요한 요 인으로 작용한 것으로 판단된다. 한편, 여학생들은 정서 적 공감이나 심리적 조력 등과 같은 물리적 이상의 사회 적 지원(social support)에 민감하고(Kang \& Lee, 2016), 중요 타자의 역할모델(role model)에 큰 영향을 받는다(Weiss, 2000). 체육수업의 경우, 여학생들의 신 체활동을 지원하는 대상은 체육교사이다. 때문에, 체육 교사의 말과 행동에 따른 상호작용 관계는 여학생 적극적 인 신체활동에 중요한 영향요인으로 평가된다(Sallis et al., 1999). 이런 점에서, 2 차 실행의 세 번째 효과 요인
은 활발한 사회적 상호작용(학생-학생, 교사-학생)이라 할 수 있다.

\section{결론 및 제언}

본 연구에서는 실행연구 전통에 따라, SPARK 프로그 램을 기반으로 신체활동 증진을 목표로 하는 체육수업을 설계(1차 계획)하고, 1 차 실행과 반성, 재계획(2차 계 획), 2 차 실행, 그리고 실행 결과의 평가의 과정을 거쳤 다. 연구 결과를 요약하면 다음과 같다.

첫째, 1 차 실행에서는 SPARK 축구 프로그램을 매뉴 얼로 삼아 축구 단원을 계획 및 실행하였다. 실행 결과, 전체 학생의 MVPA 수준은 미국체육교육당국 ( National Association for Sport and Physical Education, $\mathrm{NASPE}$ )이 권장하는 체육수업 신체활동 기준 “수업시간 대비 MVPA 비중 50\%"(NASPE, 2005)을 상회하였으 나, 여학생의 수준은 $46.5 \%$ 로 나타났다. 여학생의 낮은 $\mathrm{MVPA}$ 수준의 원인을 찾고자 수행된 질적연구에서 확인 된 수업의 문제는 동기 문제, 체력 부담, 교사와의 상호작 용 제약으로 확인되었다. 둘째, 2 차 실행에서는 1 차에서 확인된 문제를 개선하기 위해, 건강 단원과 연계한 축구 수업, 과제 난이도 선택권 제공, 과제 활동 수의 적정화, 그리고 정서 피드백 중심 상호작용 전략을 추가해 $\mathrm{SPARK}$ 프로그램 기반 축구 수업을 재계획하였다. 2 차 실행 결과, 남녀 학생의 신체활동 수준이 증가되었으며 $(53.6 \% \rightarrow 59.7 \%)$, 특히 여학생의 MVPA 수준은 $55.8 \%$ 로 나타났고 남학생과의 격차 역시 $14.1 \%$ 에서 $7.7 \%$ 로 줄어들었다. 질적연구를 통해 재계획에 포함된 여학생 신 체활동 전략들, 특히 동기 증진, 재미와 성취를 통한 의미 제공, 그리고 사회적 상호작용(학생-학생, 학생-교사) 등 이 여학생 MVPA 증진에 기여한 전략으로 확인되었다.

SPARK 프로그램은 CATCH-P.E. 와 LEAP-P.E.와 함께 대표적인 체육수업용 신체활동 증진 프로그램이다 (Dowda et al., 2005). 국내에서도 여러 연구들을 통해 중학교 육상수업(Lee et al., 2016), 체력수업(Lee, 2014), 여고생 체력 수업(Kang \& Lee, 2017)에서 $\mathrm{MVPA}$ 증진 효과가 확인되었으며, SPARK 기반 학기 단 위 교육과정에서도 MVPA 효과가 입증되었다(Lee \& 
Park, 2017). 이러한 효과는 SPARK 프로그램의 설계 원리인 학습자 수준의 과제 활동을 통한 성취 진작, BASICS 원리를 활용한 수업 운영의 효율성 향상, 스테 이션 전략 기반의 활동 다양화, 그리고 상호교수전략에 따른 학생 간 상호작용 증진 등에 기인한 것으로 판단된 다. 또한 국내 SPARK 프로그램 적용 연구들 중 질적연 구와 혼합연구로 수행된 연구들(Lee, 2014; Lee et al., 2014)에 따르면, 증진 효과는 많이 움직일 수밖에 없는 수업, 재미있고 성취할 수 있는 수업, 긍정적 수업 분위기 등으로 확인되었다. 이는 SPARK 프로그램의 설계 원리 가 우리나라 체육수업에서도 충분히 적용가능하다는 것 을 보여주는 결과이다.

그러나, 1 차 실행과 마찬가지로 다른 선행연구들 역시 SPARK 프로그램의 MVPA 효과가 남학생에게 보다 뚜 렷하게 나타난다는 것을 보여주고 있다(Lee et al., 2016). 여학생 신체활동 전문가들은 신체활동 증진 프로 그램일지라도 여학생의 신체활동 특성을 반영하지 않을 경우 그 프로그램은 남학생용 프로그램일 가능성이 높다 고 강조하고 있다(Dishman et al., 2004; Sallis et al., 1999). 이는 여학생 신체활동을 증진시키고자 한다면 여 학생 신체활동 특성을 반영해야 한다는 것을 의미한다. 이러한 측면에서, SPARK 프로그램의 기본 전략을 토대 로, 본 연구에서 나타난 여학생 신체활동량 증진 요인(건 강기반 동기유발, 과제선택권 부여, 정서적 피드백 등)을 적극적으로 수업에 반영할 필요가 있다.

결론적으로, 국외에서 개발된 SPARK 프로그램을 기 반으로 개발된 축구수업은 남녀 학생의 MVPA 증진에 효 과적이나, 여학생의 MVPA를 증진시키기 위해서는 여학 생의 신체활동 특성을 고려한 신체활동 증진 전략이 추가 적으로 투입될 필요가 있다.

본 연구를 바탕으로 향후 연구를 제안하면 다음과 같 다. 첫째, 여학생 신체활동 실태에 관한 지속적인 파악이 요청된다. 예를 들어, 지도 내용 (스포츠 활동, 움직임 활 동, 체력운동 등), 학교의 위치(도시 vS 시골)나 특성(단 성학급 vs 혼성학급, 체육관 유·무 등), 사회적 지원 체계 등에 따른 여학생 신체활동 실태를 파악하며, 여학생의 신체활동 문제를 실증적으로 이해할 수 있는 연구가 추가 되어야 한다. 둘째, 이 연구에서는 양적 연구 결과를 질적 으로 설명하는 순차적 설명 전략을 활용한 연구를 수행하
였다. 양적 연구에서 여학생의 신체활동을 남학생의 그것 에 대비하고, 여학생의 불평이나 불만을 중심으로 질적 연구를 수행함으로써, 의도치 않게, 여학생을 남학생의 대상화 즉 남학생에 비해 부족한 여학생 혹은 여학생을 수업의 문젯거리 라는 인상을 주는 젠더화된 교육 연구의 문제를 양산하고 있지는 않은지 의문이 든다. 향후 연구 에서는 이러한 부분을 고려하는 한편, 여학생의 경험을 보다 깊이 있게 이해할 수 있는 질적 연구가 수행될 필요 가 있다. 셋째, 여학생 신체활동 증진 체육수업에 관한 사 례 연구가 활발히 제기될 필요가 있다. 구체적으로, SPARK 프로그램 외에 CATCH-P.E., LEAP-P.E., 그 리고 국내에서 개발된 $\mathrm{PACA}$ 프로그램 등의 신체활동 증 진 프로그램이 개발돼 있다. 이들 프로그램은 각각의 독 특한 접근을 활용하고 있어, 다양한 사례 연구를 통해 우 리나라 학교 현장 그리고 여학생에게 적절한 접근 방식이 논의될 필요가 있다.

\section{참고문헌}

Bailey, R. (2006). Physical education and sport in schools: A review of benefits and outcomes. Journal of school health, 76(8), 397-401.

Castelli, D. M., Centeio, E. E., Hwang, J., Barcelona, J. M., Glowacki, E. M., Calvert, H. G., et al. (2014). VII. the history of physical activity and academic performance research: Informing the future. Monographs of the Society for Research in Child Development, 79(4), 119-148.

CPPSE(Committe on Physical Activity and Physical Education in the School Environment) (2013). Educating The Student Body: Taking Physical Activity and Physical Education to School. Washington, D.C.: THE NATIONAL ACADEMIES PRESS.

Creswell, J. W. (2013). Research design: Qualitative, quantitative, and mixed methods approaches. Thousand Oaks, CA: Sage

Dishman, R. K., Motl, R. W., Saunders, R., Felton, G., Ward, D. S., Dowda, M., Pate, R. R. (2004). Self-efficacy partially mediates the effect of a school-based physical-activity intervention among adolescent girls. Preventive medicine, 38(5), 628-636.

Dowda, M., Sallis, J. F., McKenzie, T. L., Rosengard, P., Kohl III, H. W. (2005). Evaluating the sustainability of SPARK physical 
education: a case study of translating research into practice. Research quarterly for exercise and sport, 76(1), 11-19.

Fairclough, S. (2003). Physical activity, perceived competence and enjoyment during high school physical education. European Journal of Physical Education, 8(1), 5-18.

Fairclough, S., \& Stratton, G. (2005). Physical activity levels in middle and high school physical education: a review. Pediatric Exercise Science, 17(3), 217-236.

Greene, J. C. (2007). Mixed methods in social inquiry (Vol. 9). New York: John Wiley \& Sons.

Haerens, L., Kirk, D., Cardon, G., De Bourdeaudhuij, I., Vansteenkiste, M. (2014). Motivational profiles for secondary school physical education and its relationship to the adoption of a physically active lifestyle among university students. European Physical Education Review, 16(2), 117-139.

Kang, H. K., \& Lee, G. L. (2016). Analysis of relationships between societal factors and moderate vigorous physical activity, physical self-efficacy, and enjoyment among Korean elementary school students in fifth and sixth grade. The Korean Journal of Physical Education, 55(3), 249-259.

Kang, H. K. \& Lee, G. L. (2015). Levels and Areas of Physically Active Lifestyle among Korean Middle School Students and relationships to Physical Self-Efficacy. Korean Journal of Sport Science, 26(4), 904-916.

Kang, H. K., \& Lee, G. L. (2017). Design and Implementation of Physical Education Class for Female High School Students Using the Promotion Strategies of Physical Activity. The Korean Journal of Physical Education, 56(1), 287-304.

Kemmis, S., \& McTaggart, R. (2000). Participatory Action Research. Denzin H. K., \& Lincon Y. S.,(Eds.). London: Sage.

Lee, G. L.(2019). Assessment of Levels of Moderate-to-Vigorous Physical Activity in Physical Education Classes Using 3-Dimensional Accelerometer: Competition Domain. Korean Journal of Sport Science, 30(2), 258-268.

Lee, G. L. (2014). Designing and Practicing P.E. Class Based on SPARK Fitness Program. Korean Journal of Sport Science, 25(1), 157-177.

Lee, G. I., \& Huh, C. H. (2011). A study to analyse assessment status of P.E. in middle school under 2007 revised physical education curriculum. Korean Journal of Sport Pedagogy, 18(4), 39-58.

Lee, G. I., \& Kang, H. K.(2015). An Analysis of Gender Difference on Physically Active Lifestyle among Korean Middle School Students. Korean Journal of Sport Pedagogy, 22(1), 53-70.

Lee, G. L., Kim, J. G., Kim, S. W., Kim, K. O. (2014). Exploration the Effectiveness of School Physical Education System Based on Spark in Health Promotion and Empirical Meaning of Students` Life. Korean Journal of Sport Science, 25(3), 556-574.

Lee, G. L., \& Park, J. Y. (2017). The Effect of SPARK M-SPAN Based Physical Education Curriculum(1 year) on Amount of MVPA and Health Related Fitness in Middle School Students. The Korean Journal of Physical Education, 56(1), 713-726.

Lee, G. L., Shin, M. C., Park, J. Y. (2016). The effect of SPARK M-SPAN track and field classes on amount of moderate to vigorous physical activity in middle school students. The Korean Journal of Physical Education, 55(5), 699-708.

McKenzie, T. L., Sallis, J. F., Prochaska, J. J., Conway, T. L., Marshall, S. J., Rosengard, P. (2004). Evaluation of a two-year middle-school physical education intervention: M-SPAN. Medicine and science in sports and exercise, 36(8), 1382.

Merrell, K. W., \& Gueldner, B. A. (2010). Social and emotional learning in the classroom: Promoting mental health and academic success. New York: Guilford Press.

MCST(Ministry of Culture, Sports and Tourism) (2012). Survey on participation in national sports. Seoul: Ministry of Culture, Sports and Tourism.

ME(Ministry of Education) (2015). Curriculum of physical education. Ministry of Education Notice 2015-74 [Separate Book 11]. Seoul: Korea Institute for Curriculum and Evaluation.

NASPE(National Association for Sport and Physical Education)(2004). Moving into the future: National standards for physical education, 2nd edition. Reston, VA: American Alliance for Health, Physical Education, Recreation and Dance.

NASPE(National Association for Sport and Physical Education)(2005). Is it physical education or physical activity?. NASPE position statement. Strategies. 19(2), 33-34.

PAGAC(Physical Activity Guidelines Advisory Committee) (2008). Physical activity guidelines advisory committee report. Washington, DC: HHS.

Quinn, P. B., \& Strand, B. (1995). A comparison of two instructional formats on heart rate intensity and skill development. Physical Educator, 52(2), 61. 
Rosengard, P. F. \& McKenzie, T. L. (2000). SPARK: Physical Education Program GRADES 6-8. San Diego, CA: School Specialty.

Sallis, J. F., McKenzie, T. L., Alcaraz, J. E., Kolody, B., Faucette, N., Hovell, M. F. (1997). The effects of a 2-year physical education program (SPARK) on physical activity and fitness in elementary school students. Sports, Play and Active Recreation for Kids. American journal of public health, 87(8), 1328-1334.

Sallis, J. F., Prochaska, J. J., Taylor, W. C., Hill, J. O., Geraci, J. C. (1999). Correlates of physical activity in a national sample of girls and boys in grades 4 through 12. Health psychology, 18(4), 410 .

Schneider, M., Dunn, A., Cooper, D. (2009). Affect, exercise, and physical activity among healthy adolescents. Journal of Sport \& Exercise Psychology, 31(6), 706-723.

Slater, A., \& Tiggemann, M. (2010). “Uncool to do sport”: A focus group study of adolescent girls' reasons for withdrawing from physical activity. Psychology of sport and exercise, 11(6), 619-626.

Strong, W. B., Malina, R. M., Blimkie, C. J., Daniels, S. R., Dishman, R. K., Gutin, B., et al. (2005). Evidence based physical activity for school-age youth. The Journal of Pediatrics, 146(6), 732-737.
Stuntz, C. P., \& Weiss, M. R. (2010). Motivating children and adolescents to sustain a physically active lifestyle. American Journal of Lifestyle Medicine, 4(5), 433-444.

Tudor-Locke, C., Craig, C. L., Aoyagi, Y., Bell, R. C., Croteau, K. A., De Bourdeaudhuij, I., et al. (2011). How many steps/day are enough? for older adults and special populations. International Journal of Behavioral Nutrition and Physical Activity, 8(1), 1.

Weiss, M. R. (2000). Motivating kids in physical activity. President's Council on Physical Fitness and Sports Research Digest.

Williams, D. M., Dunsiger, S., Ciccolo, J. T., Lewis, B. A., Albrecht, A. E., Marcus, B. H. (2008). Acute affective response to a moderate-intensity exercise stimulus predicts physical activity participation 6 and 12 months later. Psychology of sport and exercise, 9(3), 231-245.

You, J. A. (2002). A Qualitative Case Study of Good Teaching in Secondary Physical Education Classes. Korean Journal of Sport Pedagogy, 9(2), 124-154.

Yun, S. P. (2000). A Comparison Between School-Level and Teacher-Practiced Physical Education Curriculum in Middle Schools in Korea. M.A. Dissertation, Seoul university. 


\title{
여학생 신체활동 증진을 위한 방안 탐색 \\ : SPARK 프로그램 적용 축구수업 실행연구
}

\author{
양태양', 이규일2 \\ 1양덕중학교 체육교사 \\ 2경북대학교 부교수
}

〔목적〕 본 연구의 목적은 최근 체육수업 신체활동 증진 프로그램으로써 활발히 적용되고 있는 SPARK 프 로그램을 수정 - 보완해 여학생 신체활동 증진 방안을 탐색하는 것이다. 〔방법〕 연구 목적을 수행하기 위해, 본 연구는 실행연구 전통에 따라 SPARK 축구 프로그램의 여학생 신체활동 문제 파악(1차 실행 및 반성), 문제해결계획(재계획), 재계획된 SPARK 축구 프로그램의 실행과 평가(2차 실행 및 반성)의 절차로 진행되 었다. 자료의 수집과 분석은 순차적 설명 전략에 따라 이루어졌다. 구체적으로, 3 차원 가속도계를 활용해 체육 수업의 신체활동량을 측정하였고, 질적 연구도구(관찰, 수업 노트, 면담)을 활용해 참여학생의 경험을 이해할 수 있는 자료를 수집하였다. 수집된 자료를 분석하기 위해 Greene(2007)의 혼합연구 분석법을 활용하였다. 〔결과〕1차 실행 (2014년 10월 11월) 결과, SPARK 프로그램은 체육수업 전반의 신체활동량을 증진시키 지만, 여학생의 신체활동량은 남학생에 비해 상대적으로 저조하였다. 여학생의 낮은 신체활동 이유로 동기없 는 수업, 부담되는 수업, 소외되는 수업 등이 밝혀졌으며, 이를 교수 전략으로 구체화해 2 차 실행을 재계획 및 실행하였다(2015년 5월 6월). 1차 실행과 비교할 때, 2 차 실행의 신체활동량은 모든 강도에서 긍정적 으로 나타났으며, 여학생 MVPA에서는 통계적 차이가 확인되었다(<.01). 질적 분석 결과, 2 차 실행의 긍정적 이유는 1)'필요성'이라는 동기 자원, 2)힘들어도 의미있는 학습활동, 3)'친절'한 체육교사로 나타났다. (결론) 결론적으로, SPARK 프로그램을 수정·보완한 축구 수업의 실행은 중학교 여학생의 신체활동을 증진시킬 수 있다.

주요어: 신체활동, SPARK 프로그램, 중-고강도 신체활동(MVPA), 여학생, 실행연구, 순차적 설명 전략 